Saša Redžić

Arheološki institut Beograd

Angelina Raičković

Arheološki institut Beograd

Vladimir Miletić

Centar za nove tehnologije Viminacium

$904 “ 652 “: 550.837 .7(497.11)$

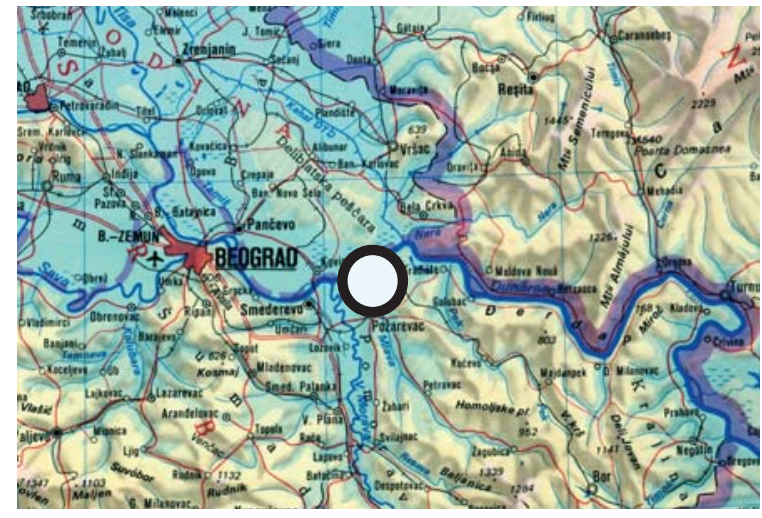

Viminacium, Stari Kostolac, Srbija

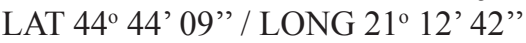

\title{
ARHEOLOŠKA ISTRAŽIVANJA LOKALITETA STIG NA OSNOVU GEORADARSKIH ISPITIVANJA
}

\begin{abstract}
ABSTRAKT
U neposrednoj blizini akvedukta koji je Viminacijum snabdevao vodom, rekognosciranjem je otkriveno, a georadarskim snimanjem i potvrđeno postojanje objekta. Nakon snimanja usledila su $i$ arheološka istraživanja koja su rezultirala, pre svega informacijom, da se radi o objektu iz kasnoantičke epohe, koji se sastojao od tri prostorije na čijoj se južnoj strani nalazila apsida.

Dimenzije otkrivenog objekta su $28 \times 12,80$ m. Radovi na otkopavanju objekta nisu završeni tj., apsida i jugozapadni deo objekta zalaze ispod lokalnog puta koji je u vreme izvođenja radova još uvek bio u upotrebi. Tokom 2005. godine, objekat je u potpunosti uništen usled nenajavljenih aktivnosti preduzetih prilikom iskopavanja uglja. Naime, lokalitet se nalazio na samom obodu površinskog kopa "Drmno".
\end{abstract}

KLJUČNE REČI: AKVEDUKT, VIMINACIJUM, GEORADAR, OBJEKAT, POKRETNI ARHEOLOŠKI MATERIJAL, VILLA RUSTICA.

Tokom rekognosciranja terena na parcelama br. 618 i 656 (koje razdvaja lokalni put br. 1579) ustanovljena je povećana kocentracija šuta, koji je zahvatao površinu 30 x 40 m. Sadržaj šuta činile su fragmentovane tegule i manji komadi lomljenog kamena zelenca koji potiče iz kamenoloma lociranog u obližnjem selu Ramu.

Gore pomenuta površina nalazila se u neposrednoj blizini akvedukta, od koga je udaljena $250 \mathrm{~m} \mathrm{u}$ pravcu istoka. Sam Viminacijum je od ove lokacije udaljen oko 2,5 km i to u pravcu severozapada.

Posle rekognosciranja, $\mathrm{u}$ navedenim parce- lama, postavljena su polja za georadarska istraživanja. Georadarska merenja izvedena u parceli br. 656 , na polju dimenzija $20 \times 30 \mathrm{~m}$, nisu dala rezultate. $\mathrm{Na}$ horizontalnom preseku snimka dobijenog merenjem u polju parcele br. 618, koje je bilo istih dimenzija kao prethodno, na dubinskom nivou od $0,30 \mathrm{~m}$, jasno su se ocrtala dva zida koja su se spajala pod pravim uglom i deo apside (sl. 1). Potom je usledila i arheološka provera rezultata snimanja georadarom, koja je u potpunosti opravdala njegovu upotrebu. ${ }^{1}$

1. Radovi su izvođeni u saradnji Arheološkog instituta i 
Ispostavilo se da situacija na terenu u velikoj meri odgovara onoj na georadarskom snimku.

Prilikom arheoloških istraživanja otkriven je objekat sa tri prostorije, na čijoj se južnoj strani nalazila apsida (sl. 3, 4).

Temeljna zona objekta pojavila se odmah ispod sloja oranice, na dubini od 0,20 m. Zidovi su građeni od lomljenog kamena zelenca i sporadičnih fragmenata opeke, međusobno vezanih krečnim malterom. Širina zidova iznosi $0,60 \mathrm{~m}$, a najveća očuvana visina $0,45 \mathrm{~m}$. Unutar zidova objekta, kao i izvan njih, otkrivena je velika količina fragmentovanih tegula i imbreksa koji bez sumnje potiču od urušenog krovnog pokrivača.

Dužina objekta iznosi oko 28 m (radovi na otkopavanju objekta nisu završeni tj., apsida i jugozapadni deo objekta zalaze ispod lokalnog puta, koji je u vreme izvođenja radova još uvek bio u upotrebi), a širina $12,80 \mathrm{~m}$ (sl. 2). ${ }^{2}$ Orijentacija objekta je sever - jug sa devijacijom $6^{\circ}$ severnim delom ka zapadu.

Treba pomenuti da je objekat u potpunosti uništen usled nenajavljenih aktivnosti preduzetih prilikom iskopavanja uglja. Naime, lokalitet se nalazio na samom obodu kopa površinskog rudnika uglja.

Unutrašnji prostor objekta raščlanjen je pregradnim zidovima na tri prostorije: prostorija 1, unutrašnjih dimenzija $6,40 \times 11,70 \mathrm{~m}$, verovatno predstavlja ulazni prostor. Njen severoistočni ugao, kao i istočna polovina severnog zida, očuvani su samo u negativu. Prostorija 2, čiju funkciju bi možda mogao da objasni ukop koji se nalazio u severoistočnom uglu, ima dimenzije 8,15 x $11,70 \mathrm{~m}$. U ukopu su se mogli videti kameni kvaderi od krečnjaka i brojni fragmenti imbreksa i tegula. Zbog prekida radova ovaj ukop nije istražen do kraja. Pregradni zid između prostorija 2 i 1 je uništen u zapadnom delu u dužini od 3,30 m. Prostorija 3 ima dimenzije 6

Republičkog zavoda za zaštitu spomenika kulture.

2. Terenske skice su crtali studenti arheologije Ivan Jevtić i Nikola Marinković. x 11,70 m i njena zapadna polovina zalazi ispod gore pomenutog puta. Pregradni zid između nje i središnje prostorije je očuvan samo $u$ istočnom delu u dužini od $0,70 \mathrm{~m}$, dok se ostatak prati samo u negativu. Oko istočnog zida prostorija 1 i 2 nađeno je više fragmenata ravnog stakla što upućuje na pretpostavku da je na ovom delu zida postojao prozor. Sa južne strane nalazi se već pomenuta apsida, poluprečnika oko $5 \mathrm{~m}$ koja takođe nije istražena.

Po podizanju ostataka krovnog pokrivača, na podu od nabijene zemlje nađeni su brojni predmeti, izrađeni uglavnom od metala, kao i fragmenti keramičkih posuda. Pored definisanih, nalaze od metala čine i primerci čiji oblik, zbog fragmentarne očuvanosti i korodiranosti, nije bilo moguće odrediti.

Najbrojniju grupu predmeta od gvožđa čine kovani klinovi, koji svakako potiču od srušene krovne konstrukcije. Pored klinova, od gvožđa je i ključ trougaono profilisane glave sa kružnom perforacijom u središtu i trapezoidnim telom sa dva zupca (T. I/2). Skoro identičan ključ nađen je, takođe na Viminacijumu, na lokalitetu "Više grobalja". ${ }^{3}$ Sa istog lokaliteta potiče i nož sa uskim jednoseklim sečivom, fragmentovane drške koji je izrađen u tehnici kovanja, veoma sličan našem primerku (T. I/7). ${ }^{4} \mathrm{U}$ istoj tehnici izrađen je i nož kratkog jednoseklog sečiva u obliku lista (T. I/6), za koji analogije nalazimo na primerku nađenom u grobu nekropole kod Beške. ${ }^{5}$

Predmeti izrađeni od bronze, takođe predstavljaju brojnu grupu nalaza, a među njima je najviše monetarnih nalaza (21), koji su navedeni u priloženoj tabeli. Nađena je i krstasta fibula izrađena u tehnici livenja, sa tri lukovice i poprečnom gredom u obliku trapeza. Fibuli nedostaje igla koja je za telo bila vezana šarnirom. Luk fibule je trapezoidnog preseka i ukrašen je kosim urezima (T. I/1). Na prelazu luka u stopu nalazi se zadebljanje. Stopa je ukrašena sa šest

3. Zotović, Jordović 1990, G-155, T. XXVI.

4. Zotović, Jordović 1990, G1-220, T. CLXXII.

5. Marijanski-Manojlović 1987, 43, G-77, T. 42. 
koncentričnih krugova. Identične fibule potiču iz Singidunuma i sa lokaliteta Gomolava. ${ }^{6}$ Pored fibule, nađen je i deo narukvice otvorenog tipa, koja se završava stilizovanom glavom životinje (T. I/5), izrađena tehnikom livenja. Slična narukvica nađena je i u Singidunumu. ${ }^{7}$ Kopča sa trnom, izrađena je od žice okruglog preseka i na mestu oslonca trna je malo spljoštena (T. I/4). Analogiju nalazimo sa primerkom nađenim u grobu, na nekropoli kod Beške, koji je kao prilog imao novac Konstancija II kao cezara. ${ }^{8}$

Predmeti od stakla su, pored već pomenutih delova ravnog prozorskog stakla, zastupljeni svega jednim fragmentom oboda i trbuha pehara debljih zidova (T. I/3), od stakla svetlozelene boje, izrađenog tehnikom slobodnog duvanja (Isings, tip 106). Pehari ovog oblika predstavljaju česte nalaze na teritoriji Gornje Mezije. ${ }^{9}$

Nalaze od kamena čine deo kružnog žrvnja i brus nepravilnog oblika.

Iako detaljna analiza keramičkih nalaza nije urađena, pregledom materijala se može zaključiti da se radi, uglavnom o zdelama, loncima i poklopcima čiji su oblici karakteristični za IV vek. Većina je rađena od gline peskovite fakture, sive i mrkosive boje pečenja, sa vidljivim tragovima gorenja na površini. Među malobrojnim primercima čija je površina prevučena gleđu potrebno je pomenuti deo tarionika maslinasto gleđosane površine (T. I/8), kao i deo tanjira horizontalno razgrnutog oboda čija je površina prevučena mrkom gleđu (T. I/9). Veći broj identičnih posuda na Viminacijumu je nađen na prostoru Termi, a analogije nalazimo i na lokalitetima, kako Gornje Mezije tako i Panonije, takođe $\mathrm{u}$ horizontima datovanim $\mathrm{u}$ IV vek. ${ }^{10}$

Obrada navedenih nalaza, a posebno nalaza novca, omogućila je precizno datovanje nastajanja

6. Bojović 1983, 85, varijanta 5, kat. br. 416, T. XLVII; Dautova-Ruševljan, Brukner 1992, T. 13/58.

7. Antička bronza Singidunuma 1997, kat. br. 567, 331.

8. Marijanski-Manojlović 1987, 43, G-21, T. 19.

9. Ružić 1994, 51, tip VII/12b.

10. Bjelajac 1994, tip III; Brukner 1981, tip 5, T. 61/17, 18. i trajanja objekta u period od 330. do 360. godine. S obzirom na nedostatak mlađeg novca, možda bi sedmu deceniju IV veka trebalo uzeti kao vreme kada objekat gubi značaj i biva napušten. Svojim gabaritom i dimenzijama objekat delimično podseća na baziliku. Da se ipak ne radi o bazilici, ukazuju sledeće činjenice:

- nedostatak nalaza uobičajenih za ovu vrstu građevina

- unutrašnjost objekta nije raščlanjena na podužne brodove kao što je slučaj kod većine bazilika

- prevelika udaljenost objekta od gradskog jezgra Viminacijuma

- orijentacija objekta je sever-jug, što nije slučaj sa bazilikama koje su po pravilu orijentisane u pravcu istok-zapad.

$\mathrm{Na}$ osnovu gore prezentiranih činjenica, determinaciju ovog objekta kao bazilike treba u potpunosti odbaciti. Mogućnost da se radi o vili rustici dovedena je u pitanje nedostatkom sistema za grejanje. Treba pomenuti mogućnost postojanja sistema za grejanje unutar apside, koja na žalost nije istražena, kao i mogućnost grejanja pomoću mangala. Takođe postoji mogućnost da je ovaj objekat korišćen samo u letnjem periodu, dok je tokom zime njegov vlasnik boravio u gradu koji se nalazi u neposrednoj blizini. Potrebno je spomenuti da ni prostor istočno od objekta nije arheološki ispitan, te konačno opredeljenje namene objekta sa apsidom nije moguće utvrditi sa potpunom sigurnošću. Više svetla na svrhu objekta pružio bi, svakako nastavak njegovog istraživanja, ali pošto to više nije moguće usled njegovog uništenja, na osnovu do sada prikupljene građe, sa dosta sigurnosti se može reći, da se u ovom slučaju radi o vili rustici skromnih razmera. U dostupnoj literaturi, za dotičnu vilu nisu nađene analogije u susednim provincijama - Panoniji, Dalmaciji, Gornjoj i Donjoj Meziji, ${ }^{11}$ ali ni u zapadnim provincijama Rimskog carstva. ${ }^{12}$

11. Thomas 1964, Vasić 1970, Динчев 1997.

12. Persival 1976. 


\section{KATALOG NOVCA}

Novac je određen prema Late Roman Bronze Coinage, London (LRBC).

\begin{tabular}{|c|c|c|c|c|c|c|c|}
\hline Br. & Vladar & Kovnica & Nom. & Dat. & $\begin{array}{l}\text { Referenca/ } \\
\text { napomena }\end{array}$ & $\begin{array}{c}\text { Preč. } \\
\text { mm }\end{array}$ & $\begin{array}{c}\text { Tež. } \\
\text { gr }\end{array}$ \\
\hline 1. & VRBS ROMA & Solun & AE3 & $330 / 5$ & LRBC 838 & 19 & 1,81 \\
\hline 2. & Konstancije II & Solun & AE4 & $335 / 7$ & LRBC 846 & 16,8 & 1,03 \\
\hline 3. & Konstancije II & Sisak & AE3 & $337 / 41$ & LRBC 767 & 17,4 & 1,09 \\
\hline 4. & Konstancije II & Herakleja & AE3 & $337 / 41$ & LRBC 948 & 17,3 & 1,27 \\
\hline 5. & Konstantin & Antiohija & AE4 & $337 / 41$ & LRBC 1374 & 16,8 & 1,26 \\
\hline 6. & - & - & AE4 & $335 / 41$ & $\begin{array}{l}\text { Tip GLORIA EXERC } \\
\text { ITVS }-1 \text { standard }\end{array}$ & 14,6 & 1,50 \\
\hline 7. & Konstantin & Nikomedija & AE4 & $341 / 6$ & LRBC 1148 & 15,3 & 1,35 \\
\hline 8. & Konstancije II & Solun & AE3 & $341 / 6$ & LRBC 859 & 17,2 & 1,54 \\
\hline 9. & Konstancije II & Solun & AE4 & $341 / 6$ & LRBC 862 & 16,4 & 1,56 \\
\hline 10. & Konstans & Akvileja & AE4 & $341 / 6$ & LRBC 702 & 14,5 & 1,51 \\
\hline 11. & Konstans & Solun & AE4 & $341 / 6$ & LRBC 860 & 16,7 & 1,00 \\
\hline 12. & Konstans & Nikomedija & AE4 & $341 / 6$ & LRBC 1150 & 16,1 & 1,30 \\
\hline 13. & - & Solun & AE4 & $341 / 6$ & $\begin{array}{l}\text { Tip VICTORIAEDD } \\
\text { AVGGQNN }\end{array}$ & 16,5 & 0,63 \\
\hline 14. & - & Solun & AE4 & $341 / 6$ & $\begin{array}{l}\text { Tip VICTORIAEDD } \\
\text { AVGGQNN }\end{array}$ & 16,4 & 1,28 \\
\hline 15. & - & - & AE4 & $341 / 6$ & $\begin{array}{l}\text { Tip VOT XX MVLT } \\
\text { XXX }\end{array}$ & 13,5 & 1,27 \\
\hline 16. & Konstancije II & Akvileja & AE2 & $346 / 50$ & LRBC 890 & 22,5 & 4,68 \\
\hline 17. & Konstans & Solun & AE3 & $346 / 50$ & LRBC 1642 & 19,9 & 2,89 \\
\hline 18. & $\begin{array}{l}\text { Konstancije } \\
\text { Gal }\end{array}$ & - & AE3 & $351 / 54$ & $\begin{array}{l}\text { Tip FEL TEMP RE } \\
\text { PARATIO pali konjanik }\end{array}$ & 19,1 & 1,29 \\
\hline 19. & - & - & AE3 & $346 / 61$ & $\begin{array}{l}\text { Tip FEL TEMP RE } \\
\text { PARATIO pali konjanik }\end{array}$ & 17,1 & 1,12 \\
\hline 20. & Konstancije II & Nikomedija & AE2 & $351 / 4$ & LRBC 2300 & 23,7 & 4,50 \\
\hline 21. & Konstancije II & Sisak & AE2 & 350 & LRBC 1169 & 24,6 & 1,83 \\
\hline
\end{tabular}




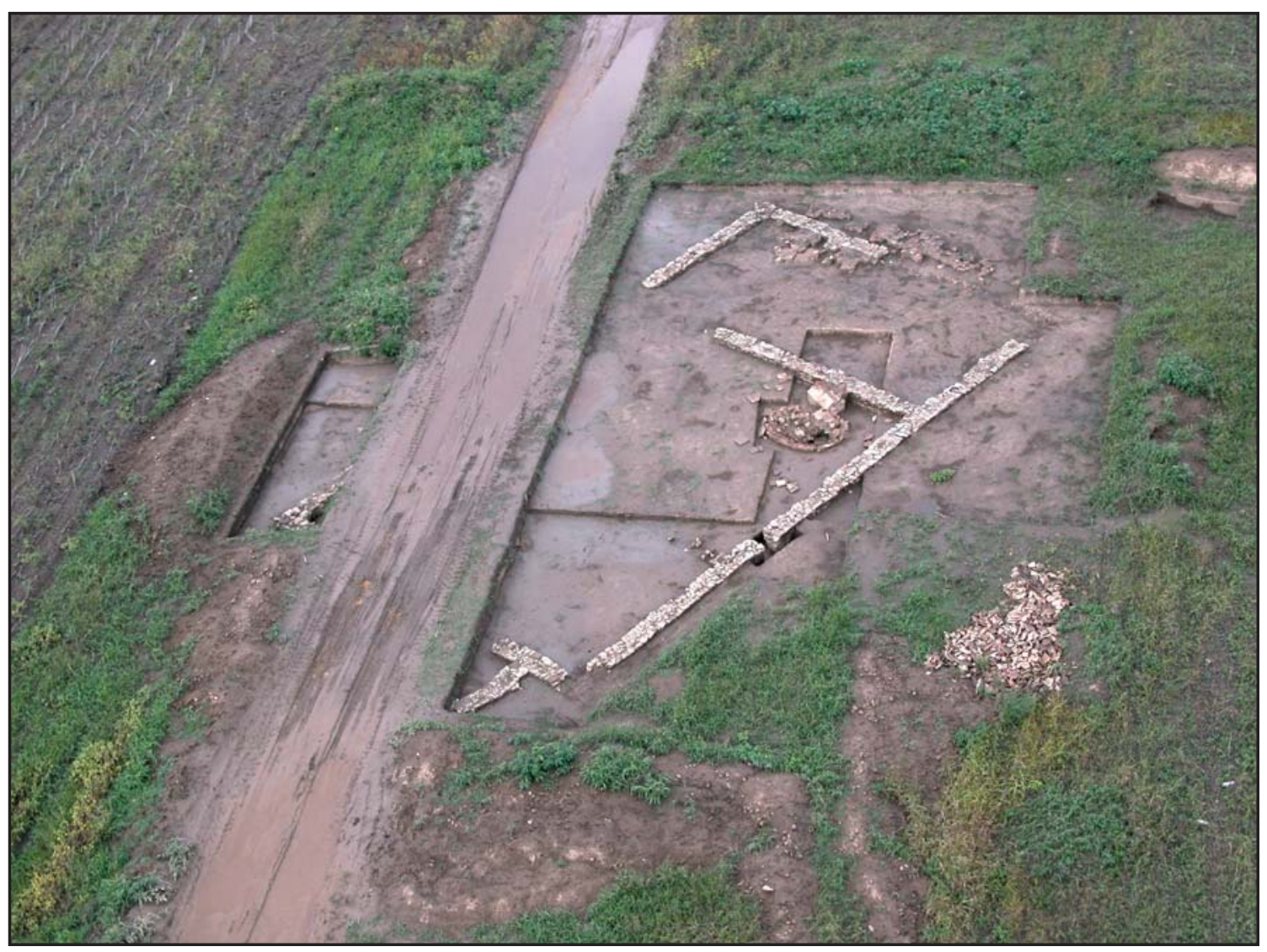

Snimak vile rustike iz vazduha (foto: M. Korać)

\section{RESUME}

\section{Archaeological Research at Site "Stig" Based on GPR Survey}

During field survey, in the vicinity of the Viminacium aqueduct, a big concentration of debris was discovered, which immediately lead to geo-radar measuring of this area. The picture clearly showed walls of an object, which lead to the excavation of the area. Archaeological excavation showed that it was an object consisting of three rooms with an apses on the southern side.

The object measures approx. $28 \times 12,80 \mathrm{~m}$. It is not yet fully under covered, because its apses and the south-western part lie under a local road which was still in use during the excavation. In 2005, the object which lied next to the edge of a nearby open cast, was completely destroyed due to unannounced activities.
The object is orientated in the north-south direction, with a deviation of its northern part by $6^{\circ}$ towards the west.

Small finds consist of the following objects: pottery fragments, several iron nails, an iron key, two iron knives, a millstone, a whetstone, a fragment of a grass beaker, a cross-like fibula made of bronze, a fragment of a bronze bracelet, a bronze buckle, as well as 21 bronze coins.

The analysis of the finds named above, especially coins, made it possible to date the object very precisely, which covers the span between 330 and 360 .

According to the position and to the finds discovered within it, one is allowed to conclude that this object presented a smaller villa rustica.

Translated by M. Tapavički-Ilić 


\section{BIBLIOGRAFIJA}

\section{Antička bronza Singidunuma 1997}

S. Krunić et. alii, Antička bronza Singidunuma, Katalog izložbe Muzeja grada Beograda, Beograd 1997.

\section{Bjelajac 1994}

Lj. Bjelajac, Mortaria in the Moesia Danube Valley, Starinar XLIII-XLIV, Beograd 1994, 139-148.

\section{Bojović 1983}

D. Bojović, Rimske fibule Singidunuma, Beograd 1983.

\section{Dautova - Ruševljan, Brukner 1992}

V. Dautova-Ruševljan, O. Brukner, Gomolava, Novi Sad 1992.

\section{Динчев 1997}

В. Динчев, Римските вили в днешната Българска територия, София 1997.

\section{Isings 1957}

C. Isings, Roman Glass from dated Finds, Groninngen - Jakarta 1957.

\section{Marijanski-Manojlović 1987}

M. Marijanski-Manojlović, Rimska nekropola kod Beške u Sremu, Novi Sad 1987.

\section{Mócsy 1974}

A. Mócsy, Pannonia and Upper Moesia, London and Boston 1974.

\section{Persival 1976}

J. Persival, The Roman Villa, London 1974.

\section{Ružić 1994}

M. A. Ružić, Rimsko staklo u Srbiji, Beograd 1994.

\section{Thomas 1964}

E. T. Thomas, Römische Villen in Pannonien, Budapest 1964.

\section{Vasić 1970}

M. Vasić, Römische Vilen von Typus der Villa rustica auf jugoslavischen Boden, Archaeologica Jugoslavica X, 1970 (1973), 45-81.

\section{Zotović, Jordović 1990}

Lj. Zotović, Č. Jordović, Nekropola «Više grobalja», Viminacium 1, Beograd 1990. 


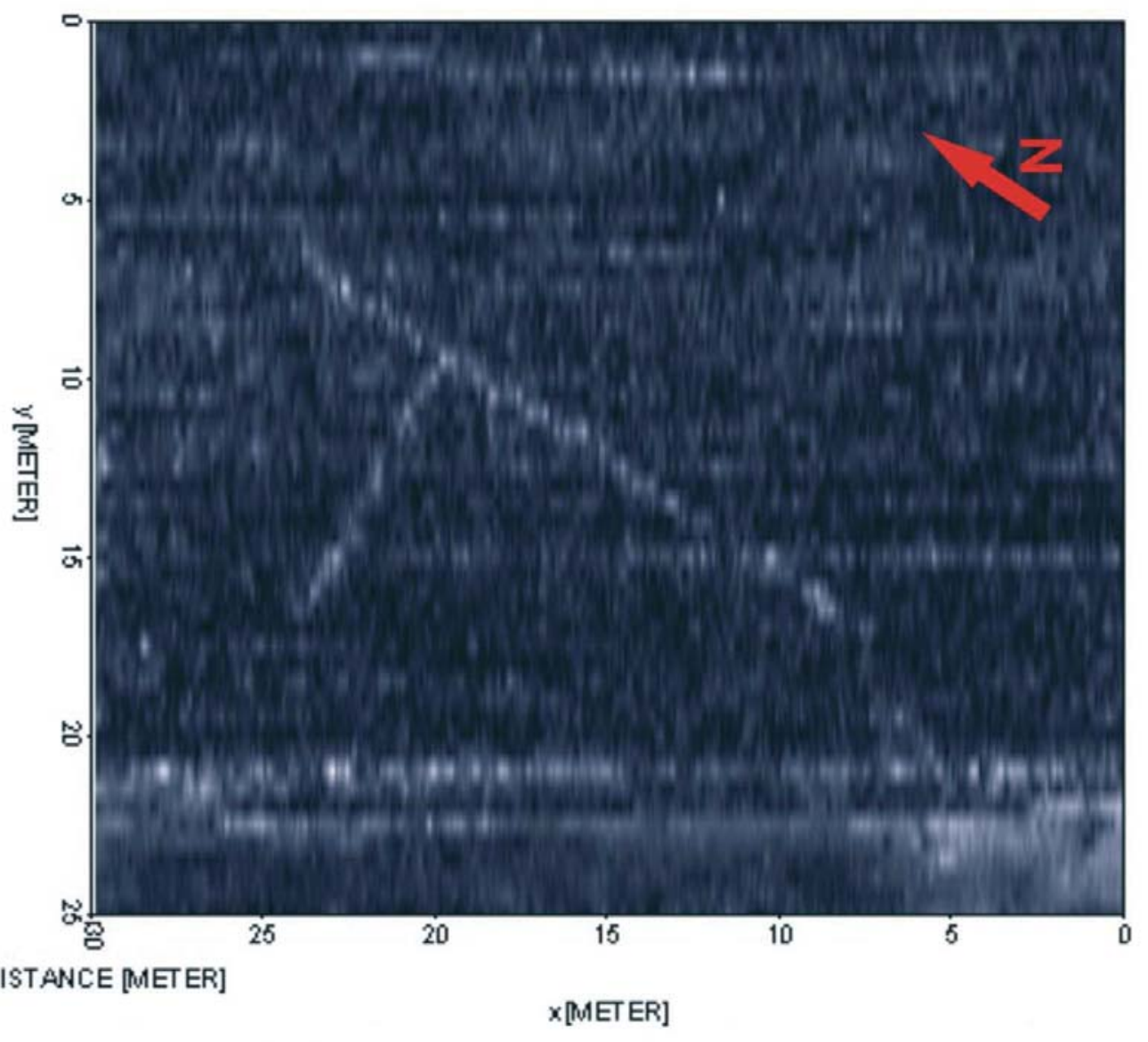

Slika 1. Horizontalni presek lokaliteta načinjen na osnovu georadarskih profila 


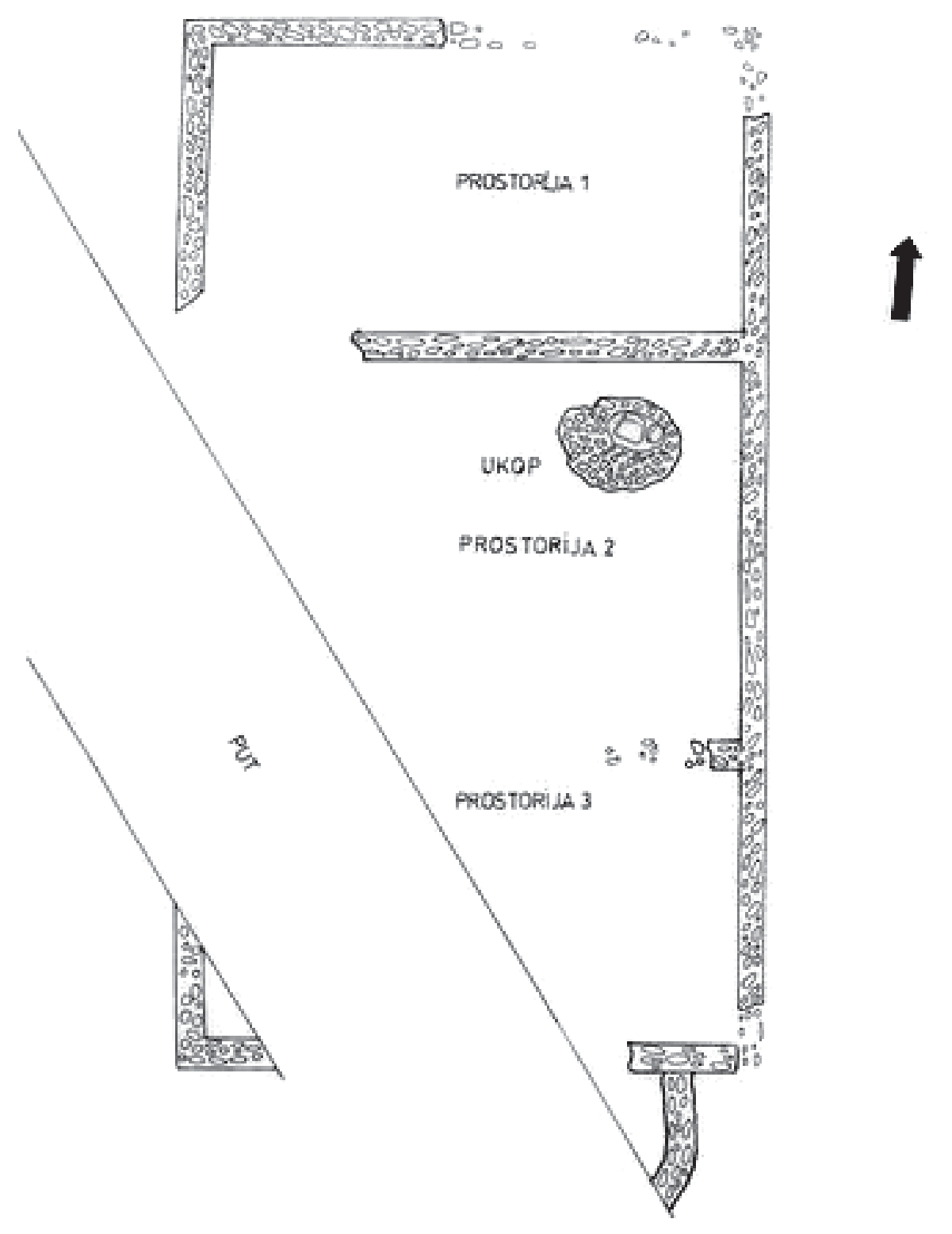

Slika 2. Osnova objekta sa apsidom (crtao N. Marinković) 

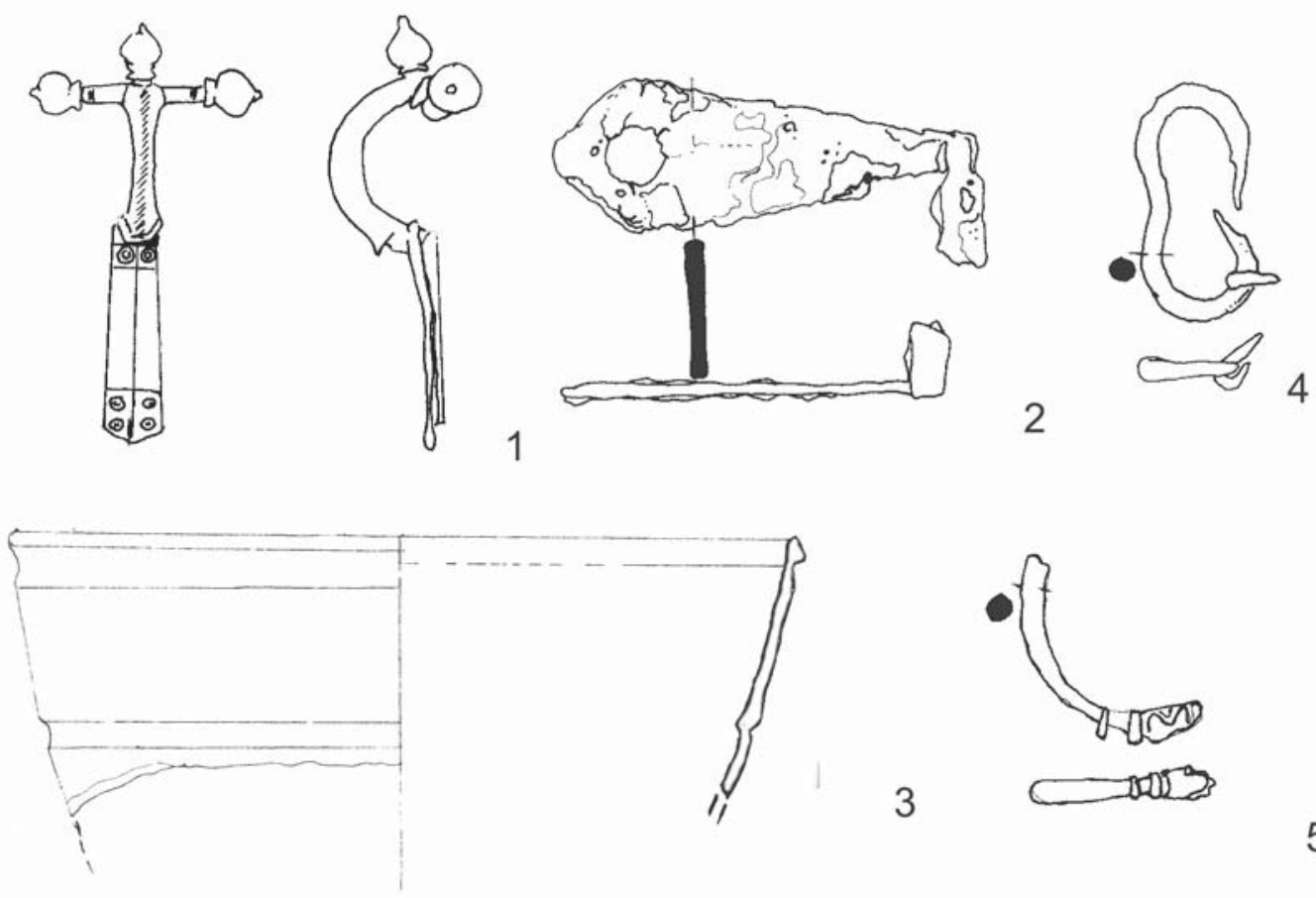

1
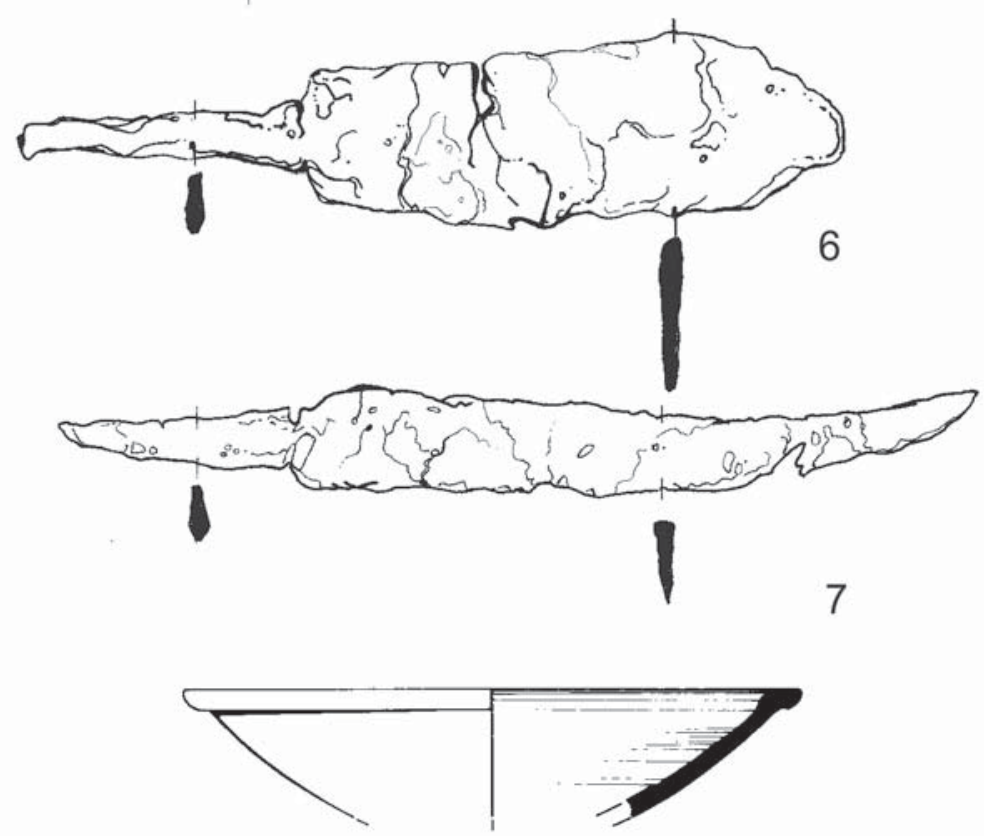

9

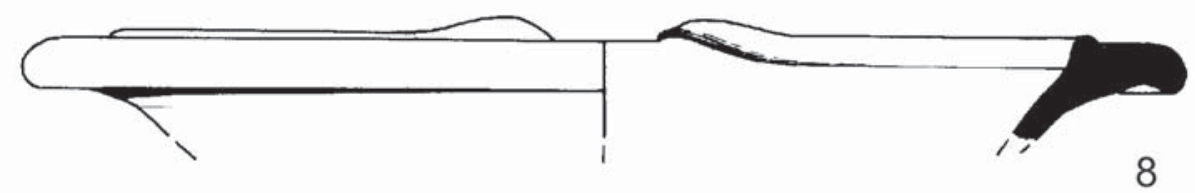

T. I: 1. Fibula - bronza, 2. Ključ - bronza, 3. Čaša - staklo, 4. Pređica - bronza,

5. Narukvica - bronza, 6. Nož - gvožde, 7. Nož - gvožđe, (1 - 7 R $2: 3$ ) 8. Tarionik - keramika, 9. Tanjir - keramika (8 i 9 R $1: 4)$ crtao: N. Marinković 


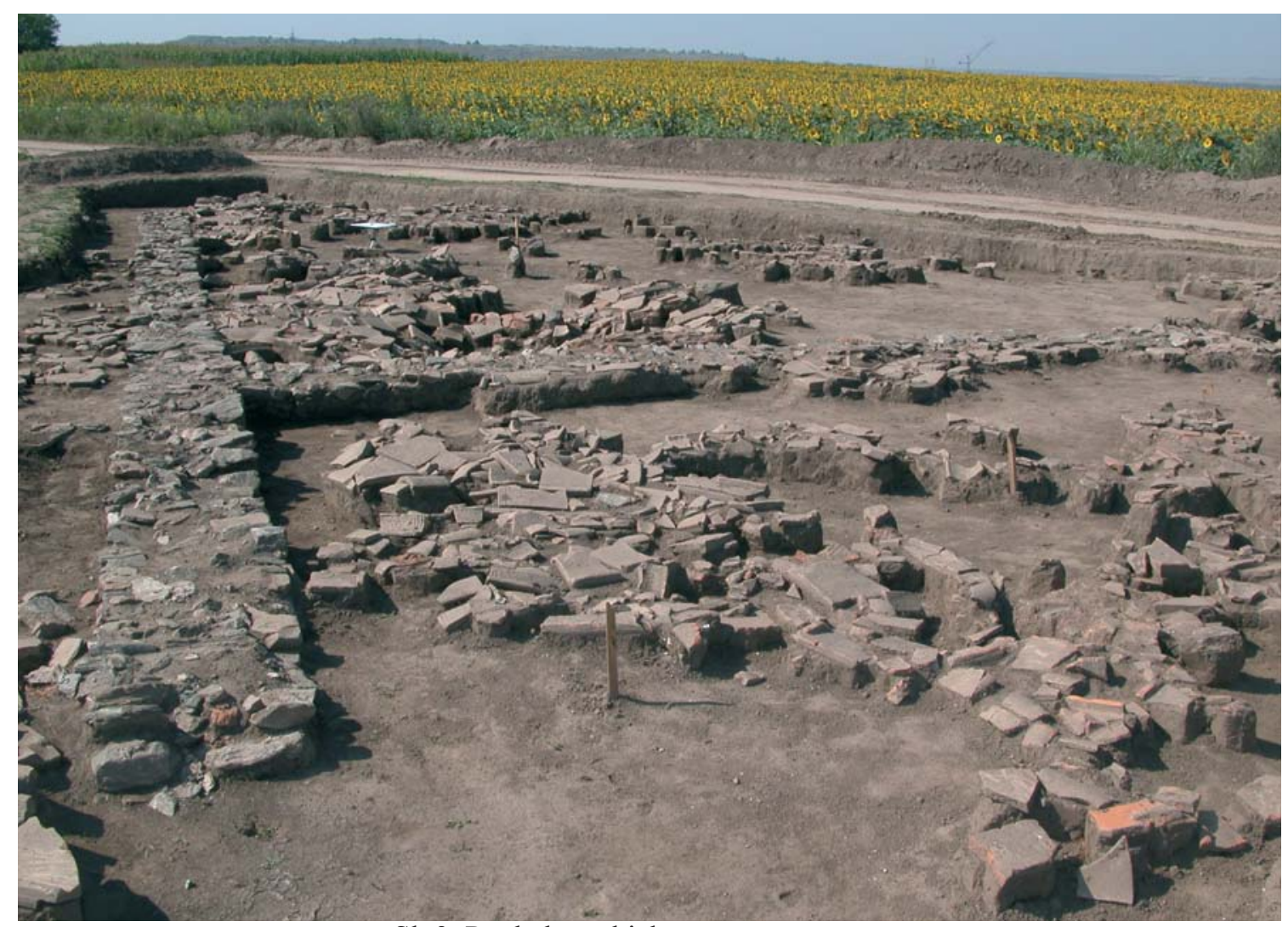

Sl. 3. Pogled na objekat sa severne strane

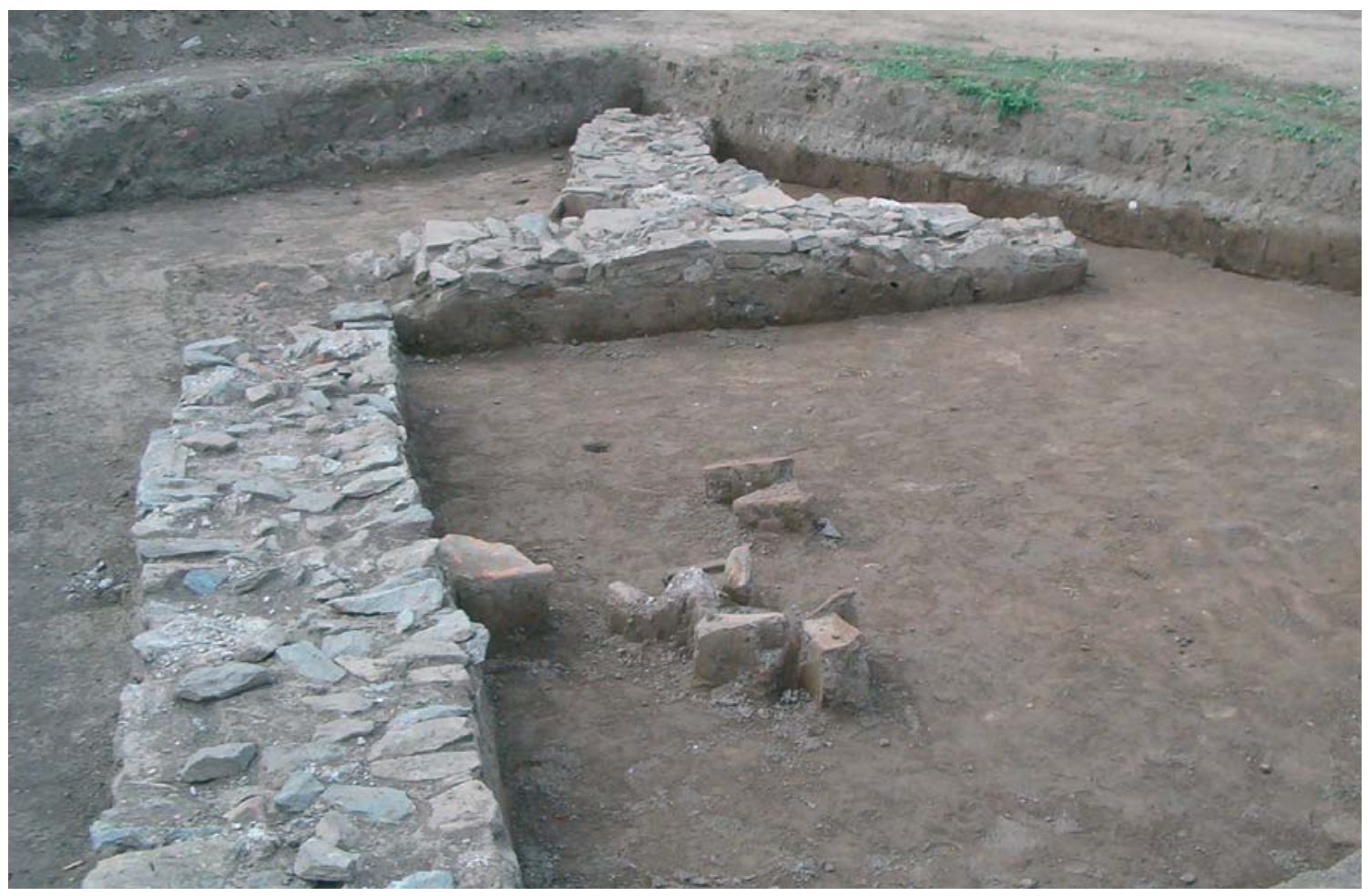

Sl. 4. Izgled istraženog dela apside sa severne strane 